\title{
Derajat merokok berhubungan dengan kadar hemoglobin pada pria usia 30-40 tahun
}

\author{
Kiki Rizky Mariani ${ }^{1}$ Kartini ${ }^{2}$
}

\begin{abstract}
ABSTRAK
LATAR BELAKANG

Merokok merupakan kebiasaan yang sering ditemui di seluruh dunia, walaupun sudah diketahui secara umum bahwa rokok dapat menimbulkan gangguan kesehatan. Beberapa penelitian meyakini bahwa merokok merupakan salah satu penyebab peningkatan konsentrasi hemoglobin dalam darah. Penelitian ini dilakukan untuk menilai hubungan kebiasaan merokok dan kadar hemoglobin pria berusia 30-40 tahun.

\section{METODE}

Penelitian observasional-analitik dengan pendekatan cross-sectional mengikutsertakan 71 pria usia 30-40 tahun di Kota Bima. Pengumpulan data kebiasaan merokok dengan wawancara kuesioner kepada responden. Kadar hemoglobin diperoleh dari pengukuran menggunakan alat Hbmeter. Analisis data menggunakan uji Chi-square dengan tingkat kemaknaan sebesar 0,05 .
\end{abstract}

\section{HASIL}

Hasil menunjukkan dari 71 responden, 35 responden tergolong derajat merokok ringan, 16 responden dengan derajat merokok sedang dan 20 responden dengan derajat berat. Terdapat 37 responden dengan jenis rokok nonfilter sedangkan 34 responden dengan jenis rokok filter. Responden dengan lama merokok lebih dari 15 tahun berjumlah 47 orang sedangkan kurang dari 15 tahun berjumlah 24 orang. Kadar hemoglobin tinggi sebanyak 37 orang, kadar hemoglobin rendah sebanyak 21 orang dan kadar hemoglobin normal sebanyak 13 orang. Analisis bivariat menyimpulkan bahwa terdapat hubungan antara derajat merokok dan kadar hemoglobin dengan nilai $\mathrm{p}=0,047$.

\section{KESIMPULAN}

Derajat merokok mempengaruhi kadar hemoglobin. Hal ini kemungkinan merupakan kompensasi tubuh terhadap kekurangan oksigen akibat afinitas $\mathrm{Hb}$ dengan karbonmonoksida yang terdapat dalam rokok.

Kata kunci : merokok, kadar hemoglobin, usia dewasa

\author{
${ }^{1}$ Program Studi Kedokteran, \\ Fakultas Kedokteran, \\ Universitas Trisakti \\ ${ }^{2}$ Departemen Ilmu Histologi, \\ Fakultas Kedokteran, \\ Universitas Trisakti

\section{Korespondensi:} \\ dr. Kartini, M.Biomed \\ Departemen Ilmu Histologi \\ Fakultas Kedokteran Universitas \\ Universitas Trisakti \\ Jalan Kyai Tapa No.1, Jakarta \\ Barat, DKI Jakarta 11440 \\ Telp: (021) 5672731 \\ Email: kartiniedwin@trisakti.ac.id
}

\author{
J Biomed Kes 2018;1(1):85-92 \\ DOI: 10.18051/JBiomedKes.2018. \\ v1.85-92 \\ pISSN: 2621-539X / eISSN: 2621-5470 \\ Artikel akses terbuka (open access) ini \\ didistribusikan di bawah lisensi Creative \\ Commons Attribution 4.0 International \\ (CC-BY 4.0)
}




\section{ABSTRACT}

\section{Degree of smoking is associated with hemoglobin concentration in males aged 30-40 years}

\section{BACKGROUND}

Smoking is a habit that is often encountered around the world, although it is commonly known that smoking could cause health problems. Some studies believe that smoking is one cause of increased hemoglobin concentrations in the blood. This study was conducted to determine association between smoking habit and hemoglobin level in 30-40 years old men.

\section{METHODS}

The observational analytical study with cross-sectional approach included 71 men aged 30-40 years in Bima city. Collection of smoking habit data by interview questionnaires to respondents. The hemoglobin level was obtained from the measurement using the Hbmeter. Data analysis using Chi-square test with significance level of 0,05 .

\section{RESULT}

Result showed from 71 respondents, 35 respondents classified mild smoking, 16 respondents with moderate smoking and 20 respondents with heavy smoking degree. There were 37 respondents with non-filter type of cigarette while 34 respondents with filter cigarette type. Respondent with smoking duration more than 15 years amounted to 47 people while less than 15 years amounted to 24 people. High hemoglobin level of 37 people, low hemoglobin level of 21 people and normal hemoglobin level of 13 people. Bivariate analysis concluded that there is correlation between degree of smoking and hemoglobin level with value $p=0,047$.

\section{CONCLUSION}

The degree of smoking affects hemoglobin levels. This is probably the body's compensation for oxygen deprivation due to the affinity of $\mathrm{Hb}$ with carbon monoxide contained in the cigarette.

Keywords : smoking, hemoglobin level, adulthood

\section{PENDAHULUAN}

Angka kematian individu ketika beranjak dewasa dua kali lipat lebih besar dari remaja dan sebagian besarnya berjenis kelamin laki-laki. Masa dewasa merupakan tahapan di mana perkembangan fisik seorang individu mencapai puncaknya dan setelah itu tubuh mulai menyusut akibat berkurangnya sel-sel yang ada di dalam tubuh dan mulai terjadi penurunan fungsi tubuh secara perlahan-lahan. Sejak memasuki usia 25 tahun perubahan-perubahan fisik mulai terlihat, secara berangsur-angsur kekuatan fisik mengalami kemunduran sehingga lebih mudah terserang penyakit. Setelah berumur 30 tahun ke atas, manusia mengalami proses penuaan yang meliputi penurunan fungsi organ tubuh, termasuk penurunan fungsi sumsum tulang yang memproduksi sel darah merah. ${ }^{1}$ Sel darah merah mempunyai protein utama yaitu hemoglobin. ${ }^{2}$

Hemoglobin merupakan salah satu senyawa dalam sel darah merah yang berfungsi mengangkut zat oksigen ke dalam sel-sel tubuh. ${ }^{3}$ Konsentrasi hemoglobin dalam darah merupakan indikator laboratorium yang paling sering digunakan dalam praktik klinis. Kadar hemoglobin yang tidak normal akan mempengaruhi kesehatan seseorang serta mengganggu proses sirkulasi darah yang ada di dalam tubuh. Banyak penelitian menunjukkan bahwa tingkat hemoglobin dipengaruhi oleh merokok. Bahaya merokok diketahui secara luas meskipun sejumlah besar orang masih terus merokok di negara-negara berkembang. ${ }^{4}$

Menurut data World Health Organization tahun 2011, pada tahun 2007 Indonesia menempati posisi ke-5 dengan jumlah perokok terbanyak di dunia. Kebiasaan merokok merupakan masalah yang terus berkembang dan belum ditemukan solusinya di Indonesia. ${ }^{5}$ Merokok pada usia anak mulai mengalami peningkatan, demikian pula pada usia remaja dan dewasa muda. ${ }^{6}$ Berdasarkan kelompok usia, presentase perokok paling tinggi berada pada usia produktif (15-64 tahun). Perilaku merokok penduduk 15 tahun ke atas masih terus mengalami peningkatan mulai dari tahun 2007 (sebesar 34,2\%) hingga 2013 (sebesar 36,3\%). Proporsi terbanyak perokok pada tahun 2013 yaitu pada usia 3034 tahun sebesar 33,4\% dan usia 35-39 tahun $32,2 \% .^{7}$ 
menunjukkan perbedaan yang signifikan antara konsentrasi hemoglobin perokok dan bukan perokok. Dari penelitian tersebut disimpulkan bahwa merokok dapat menyebabkan peningkatan konsentrasi hemoglobin ${ }^{8}$ Hasil penelitian ini didukung penelitian Makawekes MT, dkk (2016) yang menyimpulkan bahwa terdapat perbedaan signifikan antara kadar hemoglobin darah perokok dan bukan perokok. $^{3}$

$$
\text { Hasil sebaliknya didapatkan }
$$

pada penelitian Syarfaini (2013) yang memperlihatkan bahwa tidak ada hubungan yang bermakna antara kebiasaan merokok dengan kadar hemoglobin. ${ }^{9}$ Hasil ini sejalan dengan penelitian Amelia R, dkk (2016) yang menyimpulkan bahwa tidak terdapat hubungan antara derajat merokok dengan kadar hemoglobin. ${ }^{10}$

Penelitian ini bertujuan meningkatkan kesehatan masyarakat Indonesia dengan menurunkan angka perokok aktif maupun pasif dengan menganalisis hubungan antara derajat merokok, jenis rokok serta lamanya merokok dengan kadar hemoglobin pada pria usia 30-40 tahun.

\section{METODE}

Penelitian ini merupakan jenis penelitian analitik observasional dengan pendekatan potong silang (cross-sectional). Penelitian dilakukan di Dusun Lewiloa RW 03, Kelurahan Rabadompu Timur, Kota Bima, pada bulan Agustus hingga November 2017. Populasi pada penelitian ini adalah seluruh pria berusia 30-40 tahun yang menjadi penduduk dusun Lewiloa RW 03. Pemilihan sampel penelitian dengan memenuhi kriteria inklusi sebagai berikut: pria usia 30-40 tahun yang merokok, bersedia ikut dalam penelitian, dan mampu berkomunikasi dengan baik. Kriteria eksklusinya yaitu: menderita penyakit ginjal kronis, mengkonsumsi suplemen zat besi, menderita penyakit jantung dan paru, menderita anemia dan gizi buruk. Pemilihan sampel pada penelitian ini menggunakan metode consecutive non random sampling, dan diperoleh sebanyak 71 subyek penelitian yang memenuhi kriteria.
Pengumpulan data dilakukan dengan cara wawancara dan mengisi kuesioner untuk memperoleh identitas responden serta data kebiasaan merokok, setelah itu dilakukan pengukuran kadar hemoglobin menggunakan alat Hbmeter.

Analisis data menggunakan software SPSS versi 24 untuk mengolah analisis univariat yang berupa distribusi frekuensi dari karakteristik responden dan masingmasing variabel, serta analisis bivariat untuk mengetahui hubungan antar variabel dengan menggunakan uji Chi-square. Hasil disimpulkan bermakna bila nilai p lebih kecil dari tingkat signifikansi yang ditoleransi yaitu $\alpha=0,05$.

\section{HASIL}

Tabel 1. Karakteristik responden

\begin{tabular}{lcc}
\hline \multicolumn{1}{c}{ Karakterisktik } & Frekuensi (n) & \% \\
Usia (tahun) & 9 & 13 \\
30 & 5 & 7 \\
31 & 5 & 7 \\
32 & 10 & 14 \\
33 & 4 & 6 \\
34 & 3 & 4 \\
35 & 10 & 14 \\
36 & 3 & 4 \\
37 & 2 & 3 \\
38 & 5 & 7 \\
39 & 15 & 21 \\
40 & & 2,8 \\
Tingkat pendidikan & 2 & 32,4 \\
SD & 23 & 49,3 \\
SMP & 35 & 15,5 \\
SMA & 11 & \\
S1 & & \\
Pekerjaan & 14 & 19,7 \\
Wiraswasta & 46 & 64,8 \\
Petani & 9 & 12,7 \\
PNS & 2 & 2,8 \\
Nelayan & & \\
\hline
\end{tabular}

Berdasarkan tabel 1 terlihat bahwa responden berusia 40 tahun adalah yang terbanyak 15 orang (21\%). Mayoritas responden menamatkan jenjang pendidikan SMA/SMK 35 orang (49,3\%). Pekerjaan responden paling banyak adalah sebagai petani 46 orang $(64,8 \%)$. 
Tabel 2. Merokok dan kadar hemoglobin

\begin{tabular}{lcc}
\hline & Frekuensi (n) & \% \\
Derajat merokok & 35 & 13 \\
Ringan (1-10 batang/hari) & 16 & 7 \\
Sedang (11-20 batang/hari) & 20 & 7 \\
Berat ( $>20$ batang/hari) & & \\
Jenis rokok & 37 & 52,1 \\
Nonfilter & 34 & 47,9 \\
Filter & & \\
Lama merokok & 24 & 33,8 \\
$1-15$ tahun & 47 & 66,2 \\
$>15$ tahun & & \\
Kadar hemoglobin & 21 & 29,6 \\
Rendah $(<13,5$ g/dl) & 13 & 18,3 \\
Normal $(13,5-18,0$ g/dl) & 37 & 52,1 \\
Tinggi $(>18,0$ g/dl) & & \\
\hline
\end{tabular}

Berdasarkan tabel 2 mengenai kebiasaan merokok terlihat bahwa mayoritas responden merokok 1-10 batang rokok (perokok ringan) perhari 35 orang $(49,3 \%)$. Untuk jenis rokok yang digunakan baik filter maupun nonfilter jumlahnya tidak berbeda jauh. Sebagian besar responden yang merokok lebih dari 15 tahun yaitu 47 orang $(66,2) \%$, namun berdasarkan data yang diperoleh ternyata dari keseluruhan 24 responden yang merokok kurang dari 15 tahun, sebanyak 23 orang sudah merokok lebih dari 10 tahun. Sebanyak 52,1\% (37 orang) responden memiliki kadar hemoglobin $(\mathrm{Hb})$ darah yang tinggi.

Analisis bivariat mengenai hubungan derajat merokok dan kadar $\mathrm{Hb}$ dengan uji Chi-square perlu dilakukan penggabungan sel untuk variabel derajat merokok, yaitu: derajat ringan (1-10 batang rokok perhari) dan sedang-berat ( $>10$ batang rokok perhari). Berdasarkan tabel 3 terlihat bahwa perokok derajat ringan yang memiliki kadar $\mathrm{Hb}$ tidak normal sebesar $82,9 \%$, sedangkan derajat sedang-berat yang kadar Hb-nya tidak normal sebesar $80,6 \%$. Pada perokok derajat sedangberat terlihat bahwa mayoritas responden memiliki kadar $\mathrm{Hb}$ yang tinggi sebanyak 23 dari 36 orang $(63,9 \%)$. Hasil uji Chi-square menyimpulkan bahwa terdapat hubungan antara derajat merokok dan kadar hemoglobin.

Berdasarkan tabel 3 terlihat bahwa sebanyak $75,68 \%$ perokok jenis nonfilter memiliki kadar $\mathrm{Hb}$ tidak normal dan sebanyak $88,2 \%$ perokok jenis filter memiliki kadar $\mathrm{Hb}$ tidak normal. Analisis hubungan jenis rokok dan kadar hemoglobin menunjukkan bahwa tidak adanya hubungan yang bermakna.

Berdasarkan tabel 3 terlihat bahwa sebanyak $79,2 \%$ perokok yang merokok kurang dari 15 tahun memiliki kadar $\mathrm{Hb}$ tidak normal dan sebanyak $83 \%$ perokok dengan lama merokok lebih dari 15 tahun memiliki kadar $\mathrm{Hb}$ tidak normal dengan mayoritas adalah kadar $\mathrm{Hb}$ yang tinggi. Analisis hubungan lama merokok dan kadar hemoglobin menunjukkan bahwa tidak adanya hubungan yang bermakna.

\section{PEMBAHASAN}

\section{Karakteristik responden penelitian}

Pada penelitian yang dilakukan

Tabel 3. Hubungan derajat merokok, jenis rokok dan lama merokok dengan kadar hemoglobin

\begin{tabular}{|c|c|c|c|c|c|c|c|c|}
\hline & \multicolumn{7}{|c|}{ Kadar hemoglobin } & \multirow{3}{*}{ Nilai $p$} \\
\hline & \multicolumn{2}{|c|}{ Rendah } & \multicolumn{2}{|c|}{ Normal } & \multicolumn{2}{|c|}{ Tinggi } & \multirow{2}{*}{$\begin{array}{c}\text { Total } \\
\text { n }\end{array}$} & \\
\hline & $\mathbf{n}$ & $\%$ & $\mathbf{n}$ & $\%$ & $\mathbf{n}$ & $\%$ & & \\
\hline \multicolumn{9}{|l|}{ Derajat merokok } \\
\hline Ringan & 15 & 42,9 & 6 & 17,1 & 14 & 40,0 & 35 & \multirow{3}{*}{$0,047^{*}$} \\
\hline Sedang-berat & 6 & 16,7 & 7 & 19,4 & 23 & 63,9 & 36 & \\
\hline Total & 21 & 29,6 & 13 & 18,3 & 37 & 52,1 & 71 & \\
\hline \multicolumn{9}{|l|}{ Jenis rokok } \\
\hline Nonfilter & 13 & 35,14 & 9 & 24,32 & 15 & 40,54 & 37 & \multirow{3}{*}{$0,115^{*}$} \\
\hline Filter & 8 & 23,5 & 4 & 11,8 & 22 & 64,7 & 34 & \\
\hline Total & 21 & 29,6 & 13 & 18,3 & 37 & 52,1 & 71 & \\
\hline \multicolumn{9}{|l|}{ Lama merokok } \\
\hline $1-15$ tahun & 7 & 29,2 & 5 & 20,8 & 12 & 50,0 & 24 & \multirow{3}{*}{$0,923 *$} \\
\hline$>15$ tahun & 14 & 29,8 & 8 & 17,0 & 25 & 53,2 & 47 & \\
\hline Total & 21 & 29,6 & 13 & 18,3 & 37 & 52,1 & 71 & \\
\hline
\end{tabular}

*Uji Chi-square 
terhadap responden pria berusia 30-40 tahun, diperoleh hasil usia terbanyak yang mengkonsumsi rokok adalah usia 40 tahun yaitu sebanyak 15 responden (21\%). Usia 40 tahun termasuk dalam kelompok usia produktif. Namun pada usia tersebut umumnya seseorang kurang memiliki motivasi untuk memperhatikan gaya hidup dan kesehatannya. ${ }^{11}$ Salah satu gaya hidup yang tidak sehat adalah perilaku merokok. Merokok dapat mengakibatkan munculnya berbagai penyakit dalam tubuh, salah satunya berkaitan dengan hematologi. Merokok dapat meningkatkan kadar hemoglobin darah.4 Penambahan usia juga berpengaruh terhadap penurunan fungsi tubuh, sehingga adanya polutan yang masuk ke dalam tubuh akan merangsang tubuh untuk mengatasinya. ${ }^{12}$

Berdasarkan data penelitian didapatkan tingkat pendidikan terakhir responden yang merokok yaitu paling banyak pada jenjang SMA/SMK sebanyak 35 responden (49,3\%). Tingkat pendidikan SMA/SMK termasuk dalam tingkat pendidikan menengah. Tingkat pendidikan dapat mempengaruhi kualitas hidup seseorang, termasuk didalamnya gaya hidup dan status kesehatan. ${ }^{13}$ Tingkat pendidikan akan membantu responden dalam memahami tentang bahaya-bahaya yang diakibatkan oleh perilaku merokok. ${ }^{13}$ Pradono dan Sulistyowati (2014) dalam penelitiannya menyimpulkan adanya hubungan yang signifikan antara tingkat pendidikan dan status kesehatan. Lamanya tahun sekolah dapat mengembangkan kapasitas kehidupan yang efektif yang pada akhirnya akan mempengaruhi kesehatan, termasuk bergaya hidup sehat. ${ }^{14}$

Berdasarkan data penelitian didapatkan pekerjaan reponden terbanyak adalah sebagai petani yaitu sebanyak 46 responden $(64,8 \%)$. Sesuai dengan hasil Riskesdas tahun 2013 yang menyebutkan bahwa berdasarkan jenis pekerjaan, petani merupakan proporsi perokok aktif setiap hari yang terbesar dibandingkan kelompok pekerjaan lainnya. ${ }^{7}$

\section{Gambaran kebiasaan merokok dan kadar hemoglobin responden}

Analisis terhadap data kebiasaan merokok menunjukkan sebagian besar responden tergolong perokok dengan derajat ringan yaitu sebanyak 35 responden (49,3\%). Derajat sedang sebanyak 16 responden $(22,5 \%)$ dan derajat berat sebanyak 20 responden $(28,2 \%)$. Nilai derajat merokok akan mempengaruhi seberapa banyak zat kimia dalam kandungan rokok seperti nikotin, tar dan gas karbonmonoksida (CO) dari hasil pembakaran rokok yang dihisap oleh tubuh. ${ }^{15}$ Rata-rata kadar $\mathrm{Hb}$ dan karboksihemoglobin (HbCO) meningkat secara progresif sesuai dengan banyaknya rokok yang dihisap perhari. ${ }^{16}$ Banyaknya jumlah rokok yang dihisap perhari juga dipengaruhi oleh nikotin yang menimbulkan efek adiksi bagi para perokok sehingga mereka bisa merokok sampai belasan bahkan puluhan batang perhari. Selain itu faktor psikis juga turut berperan. Adanya tekanan atau stresor, menyebabkan seseorang menjadikan rokok sebagai pelarian dari keadaan tersebut. ${ }^{17}$

Dilihat dari segi jenis rokok yang dikonsumsi, sebagian besar responden mengkonsumsi rokok jenis nonfilter yaitu sebanyak 37 responden $(52,1 \%)$. Rokok jenis nonfilter umumnya memiliki kandungan nikotin dan tar yang lebih besar dibandingkan jenis filter, sehingga resiko yang ditimbulkan akibat merokok akan lebih besar. ${ }^{5,18}$ Adanya filter dimaksudkan untuk mengurangi asap yang keluar dari rokok. ${ }^{5}$ Namun pada penelitian ini tidak didapatkan adanya hubungan antara jenis rokok dengan kadar hemoglobin.

Ditinjau dari lama waktu merokok menunjukkan bahwa sebagian besar responden merokok dalam waktu lebih dari 15 tahun yaitu sebanyak 47 responden $(66,2 \%)$. Terdapat suatu zat dalam kandungan rokok yang dapat menimbulkan efek ketergantungan pada perokok. Salah satu zat yang terdapat dalam rokok adalah nikotin. ${ }^{19}$ Zat ini mempunyai efek adiksi, sehingga orang-orang yang merokok menjadi ketergantungan terhadap rokok tersebut. ${ }^{19}$ Para perokok tersebut akan mendapatkan efek psikologis berupa rasa senang dan nikmat. Apabila ketergantungan tersebut dihentikan secara tiba-tiba, maka akan menimbulkan stres bagi perokok atau pecandu nikotin tersebut. Hal inilah yang 
membuat sebagian orang merokok sampai puluhan tahun lamanya. ${ }^{19}$

Analisis terhadap data kadar hemoglobin menunjukkan sebagian besar responden memiliki kadar hemoglobin tinggi yaitu sebanyak 37 responden $(52,1 \%)$. Kadar hemoglobin yang tinggi dapat dipengaruhi oleh berbagai faktor, salah satunya adalah kebiasaan merokok. Pada seorang perokok terjadinya peningkatan $\mathrm{Hb}$ kemungkinan dimediasi oleh paparan $\mathrm{CO}^{6}$ Karbonmonoksida yang terdapat dalam rokok memiliki afinitas ratusan kali lebih kuat terhadap hemoglobin dibandingkan oksigen, sehingga terbentuk karboksihemoglobin. ${ }^{8}$ Akibat hal tersebut terjadilah penurunan kapasitas $\mathrm{Hb}$ dalam mengangkut $\mathrm{O} 2 \mathrm{ke}$ jaringan. Tubuh mengkompensasinya dengan meningkatkan kadar $\mathrm{Hb}^{16}$

\section{Hubungan antara derajat merokok dan kadar hemoglobin}

Berdasarkan hasil analisis bivariat disimpulkan bahwa terdapat hubungan signifikan antara derajat merokok dan kadar $\mathrm{Hb}$. Dalam penelitian ini menunjukkan bahwa derajat merokok mempengaruhi kadar hemoglobin, dimana perokok dengan derajat ringan maupun sedang-berat sebagian besar memiliki kadar hemoglobin yang tinggi. Hal ini disebabkan karena $\mathrm{CO}$ memiliki afinitas 200-an kali lipat lebih tinggi terhadap $\mathrm{Hb}$. Oleh karena itu $\mathrm{CO}$ yang dihasilkan dari merokok akan menggantikan oksigen untuk berikatan dengan hemoglobin dalam sel darah merah dan menghasilkan karboksihemoglobin ( $\mathrm{HbCO}$ ). Konsentrasi $\mathrm{HbCO}$ yang tinggi akan menurunkan kapasitas pengangkutan oksigen oleh hemoglobin. Kompensasi terhadap keadaan tubuh yang kekurangan oksigen, tubuh akan meningkatkan produksi hemoglobin agar pengikatan oksigen oleh hemoglobin meningkat. Hal ini sejalan dengan penelitian Shah (2012) dan Asif (2013) yang menyebutkan bahwa kadar hemoglobin pada responden yang merokok lebih tinggi daripada responden yang tidak merokok. ${ }^{20,21}$ Menurut Leifert (2008) lama paparan karbonmonoksida dan jumlah rokok yang dihisap perhari dapat mempengaruhi kadar hemoglobin. ${ }^{16}$ Pada seseorang yang merokok 40 batang atau lebih perhari terjadi peningkatan kadar hemoglobin $0,7 \mathrm{gr} / \mathrm{dl}$ lebih dibanding dengan orang yang tidak merokok. ${ }^{16}$ Hal serupa juga diungkapkan oleh Harmening (2002), bahwa merokok menyebabkan terjadinya polisitemia sekunder, terutama pada perokok berat yang merokok $20-30$ batang perhari. ${ }^{22}$ Seorang perokok berat mengalami defek transportasi oksigen yang disebabkan oleh intoksikasi karbonmonoksida yang bersifat kronik, akibatnya tubuh mengalami hipoksia jaringan. Tubuh merespon keadaan tersebut dengan meningkatkan produksi eritropoietin untuk memproduksi eritrosit lebih banyak sehingga mengakibatkan terjadinya polisitemia. ${ }^{22}$

\section{Hubungan antara jenis rokok dan kadar hemoglobin}

Berdasarkan hasil analisis bivariat disimpulkan tidak terdapat suatu hubungan signifikan antara jenis rokok dan kadar hemoglobin. Dari data penelitian didapatkan bahwa sebagian besar responden memiliki kadar hemoglobin yang tinggi baik pada rokok jenis filter maupun nonfilter. Responden dengan kadar hemoglobin tinggi paling banyak ditemukan pada perokok jenis filter. Rokok jenis filter dan nonfilter memiliki kandungan zat yang berbeda. Rokok non filter memiliki kandungan zat nikotin, tar dan $\mathrm{CO}$ yang lebih besar dibandingkan rokok filter sehingga risiko yang ditimbulkannya lebih besar. ${ }^{18}$ Walaupun rokok jenis nonfilter memiliki dampak yang lebih besar dibandingkan rokok filter, namun jumlah dan intensitas merokok setiap responden penelitian berbedabeda sehingga tidak mempengaruhi kadar hemoglobin responden. Hal ini sejalan dengan penelitian yang dilakukan oleh Syarfaini (2013) mengenai hubungan merokok dengan kadar hemoglobin yang menyebutkan bahwa jenis rokok yang dihisap tidak mempengaruhi kadar hemoglobin. ${ }^{9}$

\section{Hubungan antara lama merokok dan kadar hemoglobin}

Berdasarkan hasil analisis bivariat disimpulkan tidak terdapat suatu hubungan signifikan antara lama merokok dan kadar 
hemoglobin. Hal ini dapat disebabkan karena asupan nutrisi, aktifitas fisik serta kebiasaan merokok yang berbeda dari setiap responden yang dapat mempengaruhi nilai dari kadar hemoglobin. ${ }^{23}$ Hasil penelitian ini sejalan dengan penelitian Syarfaini (2013) mengenai hubungan merokok dengan kadar hemoglobin yang menyebutkan bahwa lama merokok tidak mempengaruhi kadar hemoglobin. ${ }^{9}$ Hasil penelitian ini juga sejalan dengan penelitian yang dilakukan oleh Susiyati (2007) mengenai hubungan kebiasaan merokok dan kadar hemoglobin dengan kesegaran jasmani yang dilakukan pada siswa SMK. Penelitian tersebut memperlihatkan bahwa tidak terdapat hubungan lama merokok dengan kadar hemoglobin. ${ }^{23}$

\section{KESIMPULAN}

Berdasarkan hasil penelitian yang telah dilakukan, maka dapat ditarik beberapa kesimpulan sebagai berikut: Terdapat hubungan yang bermakna antara derajat merokok dan kadar hemoglobin pada pria usia 30-40 tahun dan tidak terdapat hubungan yang bermakna antara jenis rokok maupun lama merokok dengan kadar hemoglobin.

\section{SARAN}

Saran bagi Kelurahan Rabadompu Timur Kota Bima agar membuat kebijakan yang dapat menurunkan konsumsi rokok serta perlu diadakan sosialisasi kepada masyarakat mengenai bahaya kebiasaan merokok. Diharapkan masyarakat dapat menghentikan konsumsi rokok yang dapat menimbulkan berbagai macam penyakit.

Hasil penelitian ini diharapkan dapat menjadi masukan bagi pengembangan penelitian selanjutnya terkait pencarian faktor-faktor lain yang dapat mempengaruhi kadar hemoglobin pada orang dewasa.

\section{UCAPAN TERIMA KASIH}

1. Dekan Fakultas Kedokteran Universitas Trisakti dr. Suriptiastuti, DAP\&E, MS, yang telah memberikan izin untuk terlaksananya penelitian ini.

2. Warga RW 03 Kelurahan Rabadompu Timur yang telah meluangkan waktunya sebagai responden dalam penelitian ini.

\section{DAFTAR REFERENSI}

1. Berk, Laura E. Development through the lifespan. 5th ed. Yogyakarta: Pustaka Pelajar;2010:247-8.

2. Rangan AA, Supit S, Engka JN. Kadar hemoglobin pada petani terpapar pestisida di Kelurahan Rurukan Kecamatan Tomohon Timur. eBm 2014;2(1):1-7.

3. Makawekes MT, Kalangi SJ, Pasiak TF. Perbandingan kadar hemoglobin pada pria perokok dan bukan perokok. eBm 2016;4(1):1-5.

4. Jasim WM. Effect of tobacco smoking on hemoglobin level among kirkuk technical institute students. MJB 2016;13(3):603-9. doi:1812-156X-13-3.

5. Setyanda YO, Sulastri D, Lestari Y. Hubungan merokok dengan kejadian hipertensi pada laki-laki usia 35-65 tahun di kota Padang. Jurnal Kesehatan Andalas 2015;4(2):434-40.

6. Riset Kesehatan Dasar. Badan penelitian dan pengembangan kesehatan. Jakarta: Kementrian Kesehatan Republik Indonesia 2007: 176-86. Available at https://www.k4health.org/sites/default/ files/laporanNasional $\% 20$ Riskesdas $\% 20$ 2007.pdf diakses pada 1 Juni 2017.

7. Riset Kesehatan Dasar. Badan penelitian dan pengembangan kesehatan. Jakarta: Kementrian Kesehatan Republik Indonesia 2013: 135-8. Available at http:// www.depkes.go.id/resources/download/ general/Hasil\%20Riskesdas\%202013.pdf diakses pada 1 Juni 2017.

8. Goel A, Deepak D, Gaur N. Study of relationship of tobacoo smoking with haemoglobin concentration in healthy adults. JPBMS 2010;01(19):1-3.

9. Syarfaini. Hubungan kebiasaan merokok dengan kadar hemoglobin siswa kelas X dan kelas XI SMA Negeri 10 Makassar tahun 2012. Jurnal Kesehatan 
2013;6(1):44-54.

10. Amelia R, Nasrul E, Basyar M. Hubungan derajat merokok berdasarkan Indeks Brinkman dengan kadar hemoglobin. Jurnal Kesehatan Andalas 2016;5(3):61921.

11. Dariyo A. Psikologi perkembangan remaja. Bogor Selatan: Ghalia Indonesia;2007:14-7.

12. Sacher R. Tinjauanklinis hasil pemeriksaan laboratorium. Jakarta: EGC;2004:4-7.

13. Suliha U. Pendidikan kesehatan dalam keperawatan. Jakarta: EGC;2012:89-92.

14. Pradono J, Sulistyowati N. Hubungan antara tingkat pendidikan, pengetahuan tentang kesehatan lingkungan, perilaku hidup sehat dengan status kesehatan. Buletin Penelitian Kesehatan 2014;17(1):89-95.

15. Perdanakusuma D. Intoksikasi karbonmonoksida. Departemen Ilmu Bedah Plastik Fakultas Kedokteran Universitas Airlangga RSUD Dr. Soetomo. Surabaya;2012:1-20.

16. Leifert JA. Anemia and cigarette smoking. IJLH 2008;30:177-84. doi:10.1111/ j.1751-553X.2008.01067.x

17. Komalasari D, Helmi AF. Faktor- faktor penyebab perilaku merokok pada remaja. Jurnal Psikologi UGM. Universitas Gadjah Mada Press;2007:2-3.

18. Susanna D, Hartono B, Fauzan H. Penentuan kadar nikotin dalam asap rokok. Jurnal Universitas Indonesia. Jakarta: Makara Kesehatan;2003:7.

19. Fidrianny I, Soemardji AA, Supradja I. Analisis nikotin dalam asap dan filter rokok. Acta Pharmaceutica Indonesia 2007;29(3):100-4.

20. Asif M dkk. Effect of cigarette smoking based on hematological parameters: comparison between male smokers and nonsmokers. Turk J Biochem 2013; 38 (1):75-80 doi: $10.5505 / \mathrm{tjb} .2013 .49369$.

21. Shah BK, Nepal AK, Agrawal M, Sinha AK. The effects of cigarette smoking on hemoglobin levels compared between smokers and non smokers. STCJ 2012;1(1):42-4. doi:10.3126/stcj. v1i1.7985.

22. Harmening DM. Clinical hematology and fundamentals of hemostasis. Edisi ke-4. Philadelphia: FA Davis Company; 2002:272-357.

23. Susiyati E. Hubungan kebiasaan merokok dan kadar hemoglobin dengan kesegaran jasmani siswa putra Sekolah Menengah Kejuruan. Semarang: Universitas Diponegoro;2007:1-2. 